\title{
FAKTOR YANG BERHUBUNGAN DENGAN PEMBERIAN KOLOSTRUM PADA BAYI BARU LAHIR DI RSKDIA PERTIWI MAKASSAR TAHUN 2016
}

\author{
Ayatullah Harun, Jumriani \\ Akademi Kebidanan Pelamonia Kesdam VII/Wirabuana Makassar
}

\begin{abstract}
Colostrum represents the first fluid that secreted by the breast gland, containing tissue debris and residual material in the alveoli and ducts of the breast glands pre- and post-puerperium. It is also viscous liquid with yellowish color and more yellow than mature milk (Wulandari \& Handayani, 2011). This research aimed to determine the relationship of mother knowledge, family support and health officers by giving colostrum at RSKDIA Pertiwi Makassar. The methods of research by using anaytical design with cross sectional study apparoach, the sample of research is post-partum mother as many as 122 mothers. The result of research indicates that there is significant correlation between mother's knowledge with the giving of colostrum for newborn with p-value $=0.014<\alpha=0.05$, there is no significant correlation between family support and the giving of colostrum with p-value $=0.79>$ $\alpha=0.05$ and there is no correlation between health officer support with the giving of colostrum with $p$ value $=0.283>\alpha=0.05$. It can be concluded that there is a relationship between mother's knowledge with the giving of colostrum and there is no relationship between family support, and health officer support with the giving of colostrum. It is expected that mothers can increase their knowledge about colostrum delivery for newborn by following counseling of health officer as well as increasing the role of health officer by giving health program especially in improving the understanding of communities about the importance of colostrum.
\end{abstract}

Keywords: colostrum, mother's knowledge level, family support, health officer

\section{PENDAHULUAN}

Kolostrum merupakan cairan yang pertama kali di sekresi oleh kelenjar payudara, mengandung tissue debris dan residual material yang terdapat dalam alveoli dan duktus dari kelenjar payudara sebelum dan setelah masa puerperium. Kolostrum juga merupakan cairan viscous kental dengan warna kekuningkuningan lebih kuning di bandingkan dengan susu matur (Wulandari \& Handayani, 2011).

Kolostrum harus diberikan kepada bayi terlebih dahulu dan pemberian kolostrum ini dilanjutkan dengan ASI Ekslusif. Jika hal ini dilakukan, akan memberikan perkembangan jasmani, emosi, intelektual serta spiritual yang baik dalam kehidupannya dimana masa lompatan pertumbuhan otak adalah $0-6$ bulan (Roesli, 2008).

Pemberian kolostrum dapat dimulai sejak satu jam pertama bayi dilahirkan dengan melakukan praktik Inisiasi Menyusu Dini (IMD). Pendekatan IMD yang sekarang dianjurkan adalah dengan metode breast crawl (merangkak mencari payudara) setelah bayi lahir segera diletakkan di perut ibu dan dibiarkan merangkak untuk mencari sendiri puting ibunya dan akhirnya menghisapnya tanpa bantuan (Astuti, 2015).

Pemerintah mendukung kebijakan

WHO dan United Nations (Unicef) yang merekomendasikan pemberian Air Susu Ibu (ASI) satu jam setelah kelahiran sebagai tindakan penyelamatan kehidupan karena pemberian ASI awal dapat menyelamatkan 22\% dari bayi yang meninggal sebelum usia satu bulan. Menyusui satu jam pertama kehidupan yang diawali dengan kontak kulit antara ibu dan bayi dinyatakan sebagai indikator global (Maryunani, 2012).

Pada tahun 2013 cakupan pelayanan kesehatan bayi di Kota Makassar yaitu sebesar 96,67\% dimana telah mencapai target SPM nasional yaitu $90 \%$ pada tahun 2015 . Adapun status gizi pada bayi/balita tampak pada cakupan pemberian ASI ekslusif selama 3 tahun terakhir, yaitu: tahun 2012 sebanyak 8.469 bayi di beri ASI ekslusif atau sekitar $63,7 \%$ dari 13.300 bayi berumur $0-6$ bulan meningkat pada tahun 2013 sebanyak 8.950 atau sekitar $67,79 \%$ dari 13.203 bayi umur 0-6 bulan. Tahun 2014 meningkat sebanyak 9.235 bayi yang diberi ASI ekslusif atau sekitar 61,03\% 
dari 15.132 bayi umur 0 - 6 Bulan (Dinas Kesehatan Provinsi Sulawesi Selatan, 2015).

Faktor-faktor yang mempengaruhi pemberian kolostrum pada ibu nifas dipengaruhi oleh berbagai faktor, baik dari faktor ibu sendiri maupun maupun faktor dari luar. Faktor ibu seperti tingkat pengetahuan, kondisi kesehatan, sikap, paritas, dan persepsi ibu sedangkan faktor dari luar berupa dukungan orang terdekat, petugas kesehatan dan budaya dilingkungan tempat tinggal ibu. Adapun faktor-faktor yang menghambat pemberian kolostrum (ASI) dipengaruhi kurangnya pengetahuan ibu terhadap keunggulan kolostrum (ASI) dan fisiologi laktasi, kurangnya persiapan fisik dan mental Ibu, kurangnya dukungan keluarga, kurangnya dukungan lingkungan (Maryunani, 2012).

Beberapa pendapat mengatakan bahwa yang menghambat ibu menyusui dalam memberikan kolostrum dengan segera, diantaranya takut bayi kedinginan, ibu terlalu lelah untuk segera menyusui bayinya, kolostrum tidak keluar atau jumlah kolostrum tidak memadai, dan juga beberapa pendapat dan penelitian mengatakan bahwa pemberian kolostrum dapat dipengaruhi oleh tingkat pengetahuan ibu (Farida, L. Marni, 2013).

Dari hasil data Rekam Medik di RSKDIA Pertiwi Makassar melaporkan bahwa dari tahun 2013 bayi lahir sebanyak 1296, tahun 2014 bayi lahir sebanyak 2102, tahun 2015 bayi lahir sebanyak 2284, dan tahun 2016 pada periode Januari - Mei bayi lahir sebanyak 730. Berdasarkan data tersebut peneliti merasa tertarik untuk mengadakan penelitian yang berjudul faktor yang berhubungan dengan pemberian kolostrum pada bayi baru lahir di RSKDIA Pertiwi Makassar.

\section{METODE PENELITIAN \\ Jenis Penelitian}

Penelitian ini merupakan penelitian analitik dengan pendekatan Cross Sectional Study untuk mengetahui hubungan pengetahuan ibu, dukungan keluarga dan dukungan petugas kesehatan dengan pemberian kolestrum pada bayi baru lahir di RSKDIA Pertiwi tahun 2016.

\section{Lokasi dan Waktu Penelitian}

Penelitian ini dilaksanakan di RSKDIA Pertiwi Makassar, pada tanggal 1 - 30 Juni tahun 2016.

\section{Populasi dan Sampel}

Populasi dalam penelitian ini adalah seluruh ibu nifas yang di rawat di RSKDIA Pertiwi Makassar pada Bulan Juni 2016 sebanyak 176 orang. Sampel dalam penelitian ini adalah sebagian ibu nifas RSKDIA Pertiwi Makassar pada Bulan Juni tahun 2016 sebanyak 122 orang dihitung dengan menggunakan rumus sebagai berikut:

$$
\mathrm{n}=\frac{N}{1+N(d)^{2}}
$$

$$
\begin{aligned}
& \text { Keterangan: } \\
& \mathrm{n}=\text { besarnya sampel penelitian } \\
& \mathrm{N}=\text { besarnya populasi } \\
& \mathrm{d}=\text { degree of reability }(0,05) \\
& \mathrm{n}=\frac{176}{1+176(0,05)^{2}} \\
& \mathrm{n}=\frac{176}{1+0,44} \\
& \mathrm{n}=122
\end{aligned}
$$$$
\mathrm{n}=\text { besarnya sampel penelitian }
$$

Jadi, jumlah sampel yang diambil dalam penelitian ini sebanyak 122 orang.

Teknik pengambilan sampel dilakukan dengan cara random sampling yaitu dengan tujuan memberikan kesempatan kepada seluruh populasi untuk dijadikan sampel

\section{Pengolahan dan Analisis Data}

Pengumpulan data dilakukan dengan menggunakan kuesioner, pengolahan data dilakukan menggunakan sistem komputerisasi (Software Statistik). Analisis data yang digunakan dalam penelitian ini adalah analisis data univariat dan bivariat (Uji Chisquare) dengan nilai alfa sebesar 0.05 (CI 95\%).

\section{HASIL PENELITIAN}

Berikut adalah hasil penelitian berdasarkan karakteristik responden yang terdiri dari umur (tahun), pendidikan dan pekerjaan sebagai berikut: 
Tabel 1. Distribusi Karakteristik Responden berdasarkan Umur, Pendidikan dan Pekerjaan di RSKDIA Pertiwi Makassar

\begin{tabular}{ccc}
\hline Karekteristik Responden & Jumlah (n) & Persentase (\%) \\
\hline Umur (Tahun) & & \\
$20-30$ & 60 & 49,2 \\
$31-40$ & 62 & 50,8 \\
Pendidikan & & \\
SD & 28 & 23,0 \\
SMP & 35 & 28,7 \\
SMA & 29 & 23,8 \\
Diploma & 13 & 10.7 \\
Sarjana & 17 & 13,9 \\
Pekerjaan & & \\
PNS & 21 & 17,2 \\
Swasta & 65 & 53,3 \\
Lain-Lain & 36 & 29,5 \\
\hline
\end{tabular}

Berdasarkan tabel 1 di atas dapat diketahui bahwa dari 122 responden sebagian besar berada pada umur 30 - 40 tahun yaitu 62 $(50,8 \%)$ dan sebagian kecil umur responden berada pada 20 - 30 tahun yaitu 60 (49,2\%). Sebagian besar pendidikan responden SMP yaitu sebanyak $35(28,1 \%)$ dan sebagian kecil pendidikan responden Diploma yaitu 13 $(10,7 \%)$. Sedangkan berdasarkan pekerjaan, sebagian besar responden bekerja di swasta yaitu $65(53,3 \%)$ dan sebagian kecil bekerja sebagai PNS yaitu $21(17,2 \%)$.

Berdasarkan tabel 2, dapat diketahui bahwa dari 122 responden, terdapat $59(48,4 \%)$ yang diberikan kolostrum dan $63(51,6 \%)$ yang tidak diberikan kolostrum di RSKDIA Pertiwi Makassar. Responden yang mempunyai tingkat pengetahuan baik sebanyak $57(46,7 \%)$ dan tingkat pengetahuan kurang sebanyak 65 $(53,3 \%)$.

Dari 122 Responden, yang mempunyai dukungan keluarga baik sebanyak $71(58,2 \%)$ dan dukungan keluarga kurang sebanyak 51 $(41,8 \%)$. Sedangkan responden yang mempunyai dukungan petugas kesehatan baik sebanyak $66(54,1 \%)$ dan dukungan petugas kesehatan kurang sebanyak 56 (45,9\%).

Tabel 2. Distribusi Responden berdasarkan Variabel Penelitian di RSKDIA Pertiwi Makassar

\begin{tabular}{lcc}
\hline Variabel Penelitian & Jumlah (n) & Persentase (\%) \\
\hline Pemberian Kolostrum & & \\
$\quad$ Diberikan & 59 & 48,4 \\
$\quad$ Tidak diberikan & 63 & 51,6 \\
Tingkat Pengetahuan Ibu & & \\
$\quad$ Baik & 57 & 46,7 \\
$\quad$ Kurang & 65 & 53,3 \\
Dukungan Keluarga & & \\
$\quad$ Baik & 71 & 58,2 \\
$\quad$ Kurang & 51 & 41,8 \\
Dukungan Petugas Kesehatan & & \\
$\quad$ Baik & 66 & 54,1 \\
$\quad$ Kurang & 56 & 45,9 \\
$\quad$ Jumlah & 122 & 100.00 \\
\hline
\end{tabular}

Tabel 3 menunjukkan hasil analisis hubungan antara pengetahuan dengan pemberian kolostrum. Dari 122 responden tingkat pengetahuan ibu yang memberi 
kolostrum sebanyak $21(36,8 \%)$ dan yang tidak memberi kolostrum sebanyak $36 \quad(63,2 \%)$. Berdasarkan tingkat pengetahuan ibu kurang akan tetapi memberikan kolostrum sebanyak 38 $(58,5 \%)$, sementara pengetahuan ibu kurang dan tidak memberikan kolostrum sebanyak 27 $(41,5 \%)$. Dari hasil uji statistik dengan menggunakan Chi-Square diperoleh nilai $\mathrm{p}$ $(0,014)<$ nilai $\alpha(0,05)$. Maka Ho ditolak dan Ha diterima, artinya bahwa ada hubungan antara pengetahuan dengan pemberian kolostrum pada bayi baru lahir di RSKDIA Pertiwi Makassar.

Tabel 3. Hubungan Pengetahuan Ibu, Dukungan Keluarga dan Dukungan Petugas Kesehatan dengan Pemberian Kolostrum di RSKDIA Pertiwi Makassar

\begin{tabular}{|c|c|c|c|c|c|c|c|}
\hline \multirow{3}{*}{ Variabel } & \multicolumn{6}{|c|}{ Pemberian Kolostrum } & \multirow{3}{*}{ P Value } \\
\hline & \multicolumn{2}{|c|}{ Diberikan } & \multicolumn{2}{|c|}{ Tidak Diberikan } & \multicolumn{2}{|c|}{ Total } & \\
\hline & $\mathbf{n}$ & $\%$ & $\mathbf{n}$ & $\%$ & $\mathbf{n}$ & $\%$ & \\
\hline \multicolumn{8}{|l|}{ Pengetahuan Ibu } \\
\hline Baik & 21 & 36,8 & 36 & 63,2 & 57 & 100 & \multirow{2}{*}{0.014} \\
\hline Kurang & 38 & 58,5 & 27 & 41,5 & 65 & 100 & \\
\hline \multicolumn{8}{|l|}{ Dukungan Keluarga } \\
\hline Baik & 30 & 42,3 & 41 & 57,7 & 71 & 100 & \multirow{2}{*}{0.079} \\
\hline Kurang & 29 & 56,9 & 22 & 43,1 & 51 & 100 & \\
\hline \multicolumn{8}{|c|}{ Dukungan Petugas Kesehatan } \\
\hline Baik & 34 & 51,5 & 32 & 48,5 & 66 & 100 & \multirow{2}{*}{0.283} \\
\hline Kurang & 25 & 44,6 & 31 & 55,4 & 56 & 100 & \\
\hline
\end{tabular}

Hasil analisis hubungan antara dukungan keluarga dengan pemberian kolostrum. Dari 122 responden dengan dukungan keluarga baik yang memberi kolostrum sebanyak $30(42,3 \%)$ dan yang tidak memberi kolostrum sebanyak $41(57,7 \%)$. Berdasarkan dukungan keluarga kurang akan akan tetapi memberikan kolostrum sebanyak 29 $(56,9 \%)$, sementara pengetahuan ibu kurang dan tidak memberikan kolostrum sebanyak 22 $(43,1 \%)$.

Dari hasil uji statistik dengan menggunakan Chi-Square diperoleh nilai $\mathrm{p}$ $(0,079)>$ nilai $\alpha(0,05)$. Maka Ho diterima dan Ha ditolak, artinya bahwa tidak ada hubungan antara dukungan keluarga dengan pemberian kolostrum di RSKDIA Pertiwi Makassar.

Hasil analisis hubungan antara dukungan petugas kesehatan dengan pemberian kolostrum menunjukkan bahwa dari 122 responden Ibu dengan dukungan petugas kesehatan baik yang memberi kolostrum sebanyak $34(51,5 \%)$ dan yang tidak memberi kolostrum sebanyak 32 (48,5\%). Berdasarkan dukungan petugas kesehatan menunjukkan bahwa dukungan petugas kesehatan kurang akan tetapi memberikan kolostrum sebanyak 25 $(44,6 \%)$ dan yang tidak memberi kolostrum sebanyak $31(55,4 \%)$.
Dari hasil uji statistik dengan menggunakan Chi-Square diperoleh nilai $\mathrm{p}$ $(0,283)>$ nilai $\alpha(0,05)$. Maka Ho diterima dan Ha ditolak, artinya bahwa tidak ada hubungan antara dukungan petugas kesehatan dengan pemberian kolostrum di RSKDIA Pertiwi Makassar.

\section{PEMBAHASAN}

Hubungan Tingkat Pengetahuan Ibu dengan Pemberian Kolostrum

Setelah melakukan penelitian dan pengolahan data, diperoleh informasi mengenai hubungan antara tingkat pengetahuan dengan pemberian kolostrum. Dari 122 responden diperoleh bahwa rendahnya pengetahuan ibu tapi tetap memberikan kolostrum sebanyak 38 $(58,5 \%)$ hasil ini lebih tinggi dibanding pengetahuan ibu baik tapi tetap memberikan kolostrum sebanyak $21(36,8 \%)$.

Dari hasil uji statistik dengan menggunakan Chi-Square diperoleh nilai $\mathrm{P}$ $(0,014)<$ nilai $\alpha(0,05)$. Maka Ho ditolak dan Ha diterima, artinya bahwa ada hubungan antara pengetahuan dengan pemberian kolostrum pada bayi baru lahir di RSKDIA Pertiwi Makassar.

Berdasarkan tingkat pengetahuan ibu dengan kategori kurang baik lebih tinggi dibandingkan dengan kategori baik. Data 
proporsi pengetahuan lebih banyak berada pada pengetahuan yang kurang dikarenakan masih adanya ibu dengan pendidikan rendah, kurangnya keikutsertaan ibu dalam kegiatan petugas kesehatan seperti penyuluhan dan rendahnya informasi tentang pentingnya pemberian kolostrum yang diterima responden sehingga dapat mempengaruhi pengetahuan ibu dengan pemberian kolostrum pada bayi baru lahir.

Selain itu rendahnya pengetahuan ibu disebabkan karna kurangnya informasi yang diperoleh ibu baik dari media maupun penyuluhan yang dilakukan oleh tenaga kesehatan akan tetapi ibu tetap memberikan kolostrum karena pada prinsipnya banyak faktor yang membuat ibu tetap memberikan kolostrum pada bayinya seperti dukungan keluarga maupun dukungan petugas kesehatan.

\section{Hubungan Dukungan Keluarga dengan Pemberian Kolostrum}

Berdasarkan hasil yang diperoleh dimana dari 122 responden dimana dukungan keluarga yang kurang dan tidak diberikan kolostrum sebanyak 22 responden $(43,1 \%)$ hal ini lebih rendah dibandingkan responden yang dukungan keluarga yang yang baik dan memberikan kolostrum Sebanyak 30 (42,3\%) artinya semakin baik dukungan keluarga maka semakin tinggi pemberian ASI Eklusif pada bayi yang baru lahir.

Dari hasil uji statistik dengan menggunakan Chi-Square diperoleh nilai $\mathrm{P}$ $(0,079)>$ nilai $\alpha(0,05)$. Maka Ho diterima dan Ha ditolak, artinya bahwa tidak ada hubungan antara dukungan keluarga dengan pemberian kolostrum di RSKDIA Pertiwi Makassar.

Hal ini menunjukkan bahwa ibu dengan dukungan keluarga baik maka kecenderungan memberikan kolostrum semakin baik pula walaupun dalam hasil penelitian masih ada ibu yang dukungan keluarga yang rendah tapi tetap memberikan kolostrum pada bayinya data proporsi dukungan keluarga hampir seluruhnya berada pada dukungan keluarga yang baik,

Peneliti mengamsumsikan bahwa tingginya pemberian kolostrum dengan dukungan keluarga yang baik membuktikan bahwa dengan baiknya dukungan keluarga dalam pemberian kolostrum maka ibu akan lebih memberikan kolostrum lagi kepada bayinya

\section{Hubungan Dukungan Petugas Kesehatan dengan Pemberian Kolostrum}

Berdasarkan hasil penelitian diperoleh bahwa dari 122 Responden dimana dukungan petugas kesehatan yang kurang baik tapi tetap diberikan kolostrum sebesar 25 responden $(44,6 \%)$ hal ini lebih rendah dibandingkan dukungan petugas yang baik dan diberikan kolostrum sebanyak 35 responden $(51,5 \%)$ artinya semakin baik dukungan petugas semakin tinggi persentase ibu memberi kolostrum pada bayinya.

Dari hasil uji statistik dengan menggunakan Chi-Square diperoleh nilai $\mathrm{P}$ $(0,283)>$ nilai $\alpha(0,05)$. Maka Ho diterima dan Ha ditolak, artinya bahwa tidak ada hubungan antara dukungan petugas kesehatan dengan pemberian kolostrum di RSKDIA Pertiwi Makassar.

Hal ini menunjukkan bahwa tingginya dukungan petugas kepada ibu maka semakin tinggi pula persentase responden/ibu dalam memberikan kolostrum pada bayinya. Dukungan petugas kesehatan dalam hal ini diharapkan dapat menjalankan perannya seoptimal mungkin untuk memfasilitasi dan membimbing ibu termasuk tata laksana ruangan ibu nifas yang bisa mendukung pemberian kolostrum pada bayi baru lahir. Selain itu dapat pula berupa pemberian informasi melalui penyuluhan dan konseling tentang manfaat kolostrum.

\section{KESIMPULAN DAN SARAN}

Adanya hubungan antara pengetahuan ibu dengan pemberian kolostrum pada bayi baru lahir di RSKDIA Pertiwi Makassar tahun 2016. Tidak adanya hubungan antara dukungan keluarga dengan pemberian kolostrum pada bayi baru lahir di RSKDIA Pertiwi Makassar tahun 2016. Tidak adanya hubungan antara dukungan petugas kesehatan dengan pemberian kolostrum pada bayi baru lahir di RSKDIA Pertiwi Makassar tahun 2016.

Diharapkan ibu dapat meningkatkan pengetahuan tentang pemberian kolostrum pada bayi baru lahir dengan mengikuti penyuluhan dari tenaga kesehatan serta peningkatan peran petugas kesehatan dalam memberikan program kesehatan khususnya dalam meningkatkan pemahaman masyarakat tentang pentingnya kolostrum pada bayi baru lahir. 


\section{DAFTAR PUSTAKA}

Astuti, D. (2015). Tingkat Pengetahuan Ibu Nifas tentang Kolostrum dengan Motivasi Pemberian Kolostrum di Rumah Sakit Panembahan Senopati Bantul Yogyakarta. Jurnal Ners Dan Kebidanan Indonesia, 3(3).

Dinas Kesehatan Provinsi Sulawesi Selatan. (2015). Profil Kesehatan Sulawesi Selatan Tahun 2014.

Farida, L. Marni, C. N. (2013). Faktor-Faktor yang Mempegaruhi Ibu Dalam
Pemberian Kolostrum Pada Bayi Baru lahir di Puskesmas Amanuban Timur. Jurnal MKM, 08(1).

Maryunani, A. (2012). Inisasi Menyusui Dini, ASI Eklusif dan Manajemen Laktasi. Jakarta: Trans Info Media.

Roesli, U. (2008). Inisiasi Menyusu Dini Plus ASI Eksklusif. Jakarta: Pustaka Bunda.

Wulandari, S., \& Handayani. (2011). Asuhan Kebidanan Ibu Nifas. Yogyakarta: Bosyen Publishing. 